2. Sevastyanov YuV, Podkolzin YuA, Maksimenko IG. Teoretiko-metodicheskie osnovyi sistemyi podgotovki sportsmenov v legkoy atletike i sportivnyih igrah. Lugansk: Znanie, 2002. $496 \mathrm{~s}$.

Цитування на цю статтю:

Тітова ГВ, Бобошко ВВ, Можин СВ. Спортивний відбір на початкових етапах підготовки юних футболістів. Вісник Прикарпатського університету. Серія: Фізична культура. 2019 Берез 26; 32: 96-102

\begin{tabular}{|c|c|}
\hline Відомості про автора: & Information about the author: \\
\hline $\begin{array}{l}\text { Timoва Ганна Вімаліївна - кандидат педагогічних } \\
\text { наук, доцент, Південноукраїнський національний } \\
\text { педагогічний університет імені К. Д. Ушинського } \\
\text { (Одеса, Україна) }\end{array}$ & $\begin{array}{l}\text { Titova Hanna Vitaliivna - Candidate of Science } \\
\text { (Education), Associate Professor (Ph. D.), South } \\
\text { Ukrainian National Pedagogical University named } \\
\text { after K. D. Ushynsky (Odesa, Ukraina) }\end{array}$ \\
\hline \multicolumn{2}{|l|}{$\begin{array}{l}\text { e-mail: fv.fontan@ gmail.com } \\
\text { https://orcid.org/0000-0003-1309-5443 }\end{array}$} \\
\hline $\begin{array}{l}\text { Бобошко Володимир Васильович - кандидат педа- } \\
\text { гогічних наук, доцент, Південноукраїнський націо- } \\
\text { нальний педагогічний університет імені К. Д. Ушин- } \\
\text { ського (Одеса, Україна) }\end{array}$ & $\begin{array}{l}\text { Boboshko Volodymyr Vasylovych - Candidate of } \\
\text { Science (Education), Associate Professor (Ph. D.), } \\
\text { South Ukrainian National Pedagogical University } \\
\text { named after K. D. Ushynsky (Odesa, Ukraina) }\end{array}$ \\
\hline \multicolumn{2}{|l|}{ https://orcid.org/0000-0002-9958-9497 } \\
\hline $\begin{array}{l}\text { Можин Серхій Вікторович - магістр, Південноук- } \\
\text { раїнський національний педагогічний університет } \\
\text { iмені К. Д. Ушинського (Одеса, Україна) }\end{array}$ & $\begin{array}{l}\text { Mozhyn Serhii Viktorovych - master, South Ukrainian } \\
\text { National Pedagogical University named after } \\
\text { K. D. Ushynsky (Odesa, Ukraina) }\end{array}$ \\
\hline
\end{tabular}

УДК 616.38-002-089.087:616-092.11 doi: 10.15330/fcult.33.102-107
Ярослав Філак, Фелікс Філак, Тетьяна Цюпак

\title{
ФІЗИЧНА ТЕРАПІЯ ХВОРИХ ПІСЛЯ ХІРУРГІЧНОГО ЛІКУВАННЯ ВИРАЗКОВОЇ ХВОРОБИ ШЛУНКА І ДВАНАДЦЯТИПАЛОЇ КИШКИ
}

Мета дослідження: вивчити та удосконалити комплексну програму реабілітації осіб після оперативного втручання у зв'язку з виразковою хворобою шлунка і 12-палої кишки в умовах санаторію. Дослідження проведено у 50 хворих. Функціональний стан шлунка вивчався інтрагастральною РНметрією, стан підшлункової залози вивчався за допомогою методики фракиійного дослідження амілази за Желтваєм (1969). Психологічне обстеження проводилось з використанням опитувальної анкети Г. Айзенка. Комплексна програма фізичної терапії включал: РГГ, дієта №5, внутрішній прийом мінеральної води Поляна Квасова, кінезіотерапію, сегментарно-рефлекторний масаж, синглетно-киснева терапія. Доведена ефективність використання комплексної санаторно-курортної терапї позитивно впливає на показники стану функціональних систем організму, підвищує ефективність відновного лікування, психоемочійний стан пацієнтів.

Ключові слова: фізична терапія, кінезіотерапія, сегментарно-рефлекторний масаж.

Aim: to study and improve the complex program of rehabilitation of persons after surgical intervention due to gastric and duodenal ulcer in the resort conditions. The study was conducted in 50 patients who underwent surgical intervention in connection with stomach and duodenum peptic ulcer age from 40 to 50 years old. The stomach functional state was studied by an intragastric $\mathrm{pH}$-metry, the state of the pancreas was studied using the method of fractional amylase examination by Zheltvay (1969). Psychological examination was carried out using the psychodiagnostic scale: a questionnaire for the determination of neuroticism H. Eysenck / variant of ERI \%. All patients underwent a course of integrated spa therapy, which included: a gentle training regimen, an RHD, a diet number 5, an internal intake of mineral water Polyana Kvasova of temperature of $42^{\circ} \mathrm{C} 45$ minutes before meals at $200 \mathrm{ml} 3$ times a day, special exercises of kinesiotherapy, segmental-reflex massage, singlet-oxygen therapy. At the examination of patients in terms of $\mathrm{pH}$, there is a hypoacidic state of the stomach, gallbladder hypotony, decreasement in the pancreas enzyme-excretory function, decreasement in the extraversion-introversion scale, high marks in the neurotic scale. As a result of the rehabilitation measures along with improving of the health state, there was a decreasement in the $\mathrm{pH}$ of the stomach's body and antrum,

( ) Філак Я., Філак Ф., Цюпак Т., 2019 
the gallbladder contractile function has improved, the parameters of the enzyme-excretory function of the pancreas has increased at fasting and during the digestion period. According to the H. Eysenck questionnaire data in patients, the low ratings on the extraversion-introversion scale have reliably increased, initially high rates of neuroticism scale have decreased. Thus, in the majority of patients who underwent surgical intervention due to stomach and duodenal ulcer, a number of early postoperative syndromes develop, which manifests as a violation of the other digestive system organs functions, mechanisms of adaptive regulation and self-regulation at different levels, changes neuropsychic sphere. The efficacy of using the complex of rehabilitation measures developed by us which are aimed at improving clinical, laboratory parameters of normalization of motorevacuator, secretory functions of the gastrointestinal tract, neuropsychiatric sphere is proved.

Key words: physical therapy, kinesiotherapy, segmental-reflex massage.

Постановка проблеми й аналіз результатів останніх досліджень. Виразкове ураження гастродуоденальної зони перебуває в центрі уваги терапевтів і хірургів, оскільки виразкова хвороба (BX) має високу питому вагу серед інших захворювань травного каналу, часто рецидивує, зумовлює численні ускладнення, що зумовлює тривалу втрату працездатності хворих. Щороку в Україні на диспансерному обліку перебуває понад 1 млн хворих на виразкову хворобу шлунка і дванадцятипалої кишки. Ця хвороба вражає людей у найбільш працездатному віці і $є$ не тільки медичною, але й соціальною проблемою. Незважаючи на велику різноманітність консервативних методів лікування, кількість хворих, які перенесли операцію на шлунку і 12-палій кишці в зв'язку з виразковою хворобою, не зменшується. У зв'язку з характером захворювання, у системі лікувально-профілактичних заходів велике значення має профілактика рецидивів. Важливими факторами профілактики виразкової хвороби $є$ правильна організація праці, побуту та харчування, а також застосування засобів фізичної терапії $[1,4]$.

Для попередження розвитку післяопераційних ускладнень, а також для зменшення проявів порушень здоров'я, якщо вони вже виникли, хворому рекомендована комплексна реабілітація. Санаторно-курортна терапія є важливою ланкою поетапного відновного лікування хворих 3 патолологією органів травлення. Одним із основних i ефективних методів відновного лікування хворих після оперативного втручання на органах черевної порожнини на будь-якому етапі відновного лікування $є$ питний прийом мінеральних вод. Для хворих, які пренесли оперативні втручання на шлунку і дванадцятипалій кишці, розроблено диференційовані підходи до фізичної терапії в санаторнокурортних умовах на підставі комплексного застосування маломінералізованих мінеральних вод. Проте і досі в проблемі санаторно-курортного лікування після оперативних втручань у зв'язку з виразковою хворобою шлунка і 12-палої кишки залишаються багато питань, які вимагають вирішення [2].

Лікувальна гімнастика $є$ методом неспецифічної терапії і розглядається як метод патогенетичної терапії, що стимулює кровообіг у черевній порожнині, малому тазі, зміцнює м'язи черевного пресу і позитивно впливає на моторну, евакуатору, секреторну функції та на нервово-психічну сферу організму. У наукових публікаціях останніх 10 років як в Україні, так і за кордоном висловлються міркування про доцільність алгоритму комплексного підходу до попередження післяопераційних ускладнень як методами санаторно-курортного лікування, так і засобами фізичної терапії. Тому комплексна і поетапна реабілітація даної категорії хворих є актуальною $[3,5]$.

Мета дослідження - вивчити та удосконалити комплексну програму фізичної терапії осіб після оперативного втручання у зв'язку з виразковою хворобою шлунка i 12-палої кишки в умовах санаторію Поляна.

Методи й організація дослідження. Нами проведено обстеження у 50 хворих, які перенесли оперативне втручання у зв'язку з виразковою хворобою шлунка і 12-палої кишки віком від 40 до 50 років, з них 40 чоловіків і 10 жінок. Всі пацієнти перенесли органоберігаючі операції з пілоропластикою по Фінею або по Гейнеке-Мікуличу. 
Тривалість часу після оперативного втручання становила від 4 до 8 років. На початку дослідження було проведено опитування хворих з метою збору скарг, з'ясування анамнезу хвороби і життя. Діагноз хронічний гастрит та хронічний холецистит базувався на клінічному, інструментальному і лабораторних методах обстеження, які проводились на початку і вкінці курсу відновного комплексного лікування. Функціональний стан шлунка вивчався інтрагастральною РН-метрією, яка проводилася за допомогою двохелектродного рН-зонда на рівні тіла і антрального відділу, стан підшлункової залози вивчався за допомогою методики ФАЖ - фракційного дослідження амілази за Желтваєм (1969). Також всім пацієнтам проводили ультразвукове обстеження жовчного міхура і підшлункової залози. Ефективність впливу на моторну та секреторну функцію органів шлунково-кишкового тракту й шлунка оцінювали за зміною витривалості сили м'язів черевного преса. Хворим пропонувалося підняти прямі ноги під кутом $45^{\circ}$ відносно опори, і втримувати в цьому положенні максимально можливий час (min - 10 сек; $\max -30$ сек). Психологічне обстеження проводилось 3 використанням психодіагностичної шкали: опитувальна анкета для визначення нейротизму Г. Айзенка /варіант EPI/, та скорочений варіант Бека шкали самооцінки депресії. Для визначення ступеня вірогідності зміни показників нами застосовувався метод математичного аналізу експериментальних даних - метод критерію t-Стьюдента.

Всі пацієнти пройшли курс комплексної санаторно-курортної терапії, яка включала: щадно-тренуючий режим, РГГ, дієта №5, внутрішній прийом мінеральної води Поляна Квасова температури $42^{\circ} \mathrm{C}$ за 45 хвилин до прийому їжі по 200 мл 3 рази в день. Хворі були поділені на дві групи. Основну групу складали 30 пацієнтів, у яких в комплекс фізичної терапії ації додатково входили засоби фізичної терапії, а саме спеціальні вправи кінезіотерапії, сегментарно-рефлекторний масаж, синглетно-киснева терапія. У комплекс рухової гімнастики входити в певній послідовності гімнастичні вправи 3 різних вихідних положень, які направлені на зміцнення м'язів живота, покращення регенеративних процесів, зменшенню запального процесу гастродуоденальної зони, нормалізації тонусу і перистальтики кишечника, відновлення психічного стану і фізичної працездатності пацієнтів. Дозування кожної вправи - 6-8 разів, тривалість занять - 3540 хвилин. Сегментарно-рефлекторний масаж передбачав вплив на відповідні паравертебральні зони і надчеревну ділянку. Тривалість масажу 20 хвилин, на курс 15 процедур. Синглетно кисневу терапію проводили інгаляційним методом. На курс 15 процедур. Другу (контрольну) групу складали 20 пацієнтів, у яких для порівняння у комплекс лікувальної гімнастики входили загальнозміцнюючі вправи для всіх м'язових груп, м'язів черевного пресу з невеликими обтяженнями у чергуванні з дихальними вправами, а також класичний масаж.

Результати і дискусія. За даними опитування практично всі пацієнти, які перенесли оперативне втручання скаржилися на відчуття важкості в епігастрії, на здуття живота, бурчання по ходу кишечника, проноси, загальну слабкість, інколи серцебиття після прийому їжі, дратівливість, емоційну нестійкість, поганий сон. При пальпації відзначали болючість в ділянці епігастрію або післяопераційного рубця 50,0\% пацієнтів основної групи та 40,0\% осіб контрольної групи. У пацієнтів основної групи хронічний гастрит шлунка виявлений у $12(40,0 \%)$ і $9(45,0 \%)$ контрольної групи, хронічний некам'яний холецист виявлений відповідно у 18 (60,0\%) осіб основної і $11(55,0 \%)$ обстежених контрольної груп, реактивний панкреатит відповідно у $8(26,7 \%)$ і 5 (25,0\%) пацієнтів обидвох груп. За показниками рН у осіб, які перенесли оперативне втручання у обидвох групах відзначається гіпоацидний стан в тілі і антральному відділі шлунка. Середній показник рівня рН тіла шлунка пацієнтів основної групи становив 2,96 0,42 ,

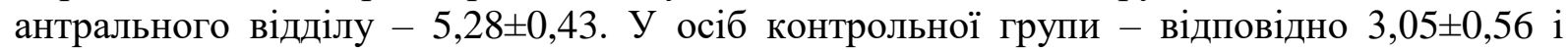




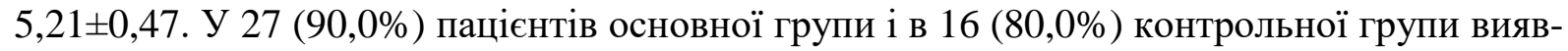
лені явища гіпомоторної дискінезії жовчовидільних шляхів, що підтверджується ультразвуковим обстеженням. Методом ФАЖ у 24 пацієнтів (80,0\%) першої групи і в 15 $(75,0 \%)$ другої групи виявленно зниження ферментовидільної функції підшлункової залози натще і в період травлення. Дані обстеження засвідчують, що у хворих обох груп виявлені приблизно однакові патологічні зміни. При обстежені у 50,0\% пацієнтів основної та 40,0\% осіб контрольної груп виявлено ознаки анемії, незначний лейкоцитоз, прискорене ШОЕ. Витривалість м'язів черевного преса для пацієнтів основної групи становило $13,6 \pm 1,9$ с і 14,6 22,1 с, що оцінювався як результат незадовільний. За даними опитувальної анкети Г. Айзенка у хворих виявлені дещо знижені оцінки за

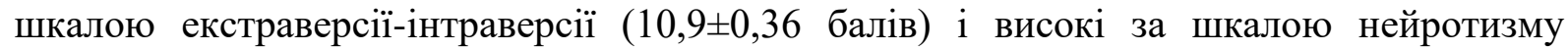
(19,2 $\pm 0,45$ балів). Найбільш високі оцінки виявлені за такими показниками шкали, як підвищена дратівливість, втрата задоволення, знижений настрій та порушення сну.

Таким чином, у більшості хворих, які перенесли оперативне втручання у зв'язку з виразковою хворобою шлунка і 12-палої кишки відзначається знижена секреторна функція шлунка, виявляються функціональні порушення з боку жовчовидільної системи та підшлункової залози та розлади моторної функції кишечника. У обстежених пацієнтів відзначались підвищена тривожність, емоційна нестійкість, знижений настрій, почуття невдоволення собою. Такі зміни зумовлені порушенням нейро-ендокринної регуляції внаслідок пристосування роботи органів травлення до нових умов функціонування.

Для визначення ефективності впливу програми фізичної терапії на клінічні показники та функціональний стан секреторної і моторно-евакуаторної функцій шлунка і 12палої кишки, стабілізацію нервової системи усім пацієнтам основної і контрольної груп в кінці курсу реабілітації проведені повторні обстеження. У результаті проведених заходів фізичної терапіїу 90,0\% пацієнтів основної групи і у 80,0\% осіб контрольної групи покращилось самопочуття. Зменшились відчуття важкості та дискомфорту в епігастpiї, загальна слабість, дратівливість, нормалізувався стілець. Застосування комплексної програми фізичної терапії вплинуло і на функціональний стан шлунка і дванадцятипалої кишки. Рівень $\mathrm{pH}$ тіла шлунка у пацієнтів основної групи достовірно знизився 3 $2,96 \pm 0,42$ до $2,09 \pm 0,44$ (Р < 0,01), в антральному відділі шлунка рівень $\mathrm{pH}$ знизився 3 $5,28 \pm 0,43$ до 4,31 $\pm 0,44$ ( $<<0,05)$. У пацієнтів контрольної групи зниження $\mathrm{pH}$ тіла

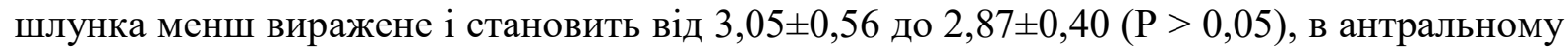

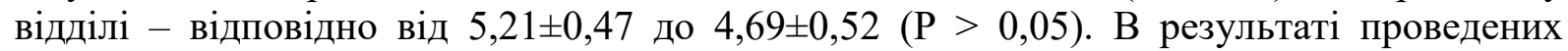
заходів фізичної терапії на фоні внутрішнього прийому мінеральної води Поляна Квасова та кінезіотерапії у 90,0\% пацієнтів основної групи і у 70,0\% контрольної групи нормалізувались показники крові. За даними повторного ультразвукового обстеження жовчного міхура у 60,0\% пацієнтів основної групи і у 40,0\% осіб контрольної групи покращилась скорочувальна функція жовчного міхура. Проведене повторно фракційне дослідження амілази у обидвох групах показало, що у пацієнтів основної групи показники ферментовидільної функції підшлункової залози натще і в період травлення підвищились у 23 (76,7\%), у осіб контрольної групи ці показники підвищились у 9 (45,0\%).

Після завершення курсу заходів фізичної терапії у пацієнтів основної групи показники витривалості м'язів черевного преса підвищились $313,6 \pm 1,9$ с. до $25,8 \pm 1,8$ с. i

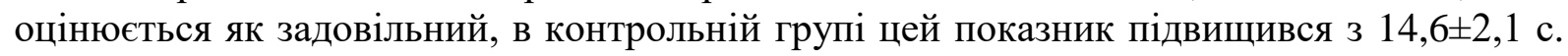
до 19,8 $\pm 2,3$ с. Покращення результатів в основній групі становило 12,2 с., тоді як у контрольній 5,2 с., що вказує на ефективність запропонованої програми. За даними опитувальної анкети Г. Айзенка у пацієнтів основної групи знижені оцінки у за шкалою екст-

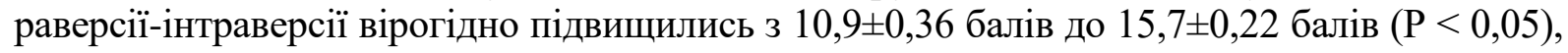


початково високі показники за шкалою нейротизму також знизились 19,2 $\pm 0,45$ балів до $14,6 \pm 0,34$ балів $(\mathrm{P}<0,05)$. У пацієнтів контрольної групи ці показники дещо гірші і ста-

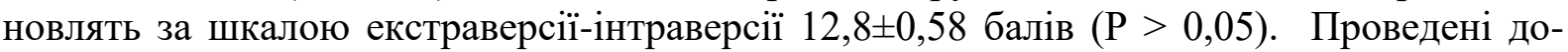
слідження свідчать, що після впровадження комплексної програми фізичної терапії у пацієнтів після хірургічного лікування з приводу виразкової хвороби покращується самопочуття, нормалізується психоемоційний стан пацієнтів, нормалізується сон. Найкращі показники виявлені у хворих основної групи.

Висновки. 1. У більшості хворих після хірургічного лікування виразкової хвороби шлунка і 12-палої кишки розвиваються ряд післяопераційних синдромів, які проявляється порушенням функцій інших органів шлунково-кишкового тракту, змінами нервово-психічної сфери.

2. Застосування засобів комплексної фізичної терапії позитивно впливає на об'єктивні показники функціонування шлунка, жовчних шляхів, підшлункової залози, підвищує ефективність відновного лікування та покращує психоемоційний стан пацієнтів після хірургічного лікування виразкової хвороби шлунка і 12-палої кишки.

1. Выгоднер ЕБ. Физические факторы в гастроэнтерологии. М.: Медицина, 1987. 304 с.

2. Методи ранньої курортної реабілітації хворих, які перенесли холецистектомію, ваготомію та резекцію шлунка: метод. реком. / Укр. НДІ МР та К; Склад.: Драгомирецька Н.В., Серебріна Л.О., Бондарчук Г.Ф. Одеса, 1995. $21 \mathrm{c.}$

3. Пархотик ИИ. Физическая реабилитация при заболеваниях органов брюшной полости. К.: Олимпийская литература, 2003. 223 с.

4. Самсонов МА, Лоранская ТИ, Нестерова АП. Постгастрорезекционные синдромы (патогенез, клиника, лечение) / АМН СССР. М.: Медицина, 1984. 192 с.

5. Серебрина ЛА. Реабилитация больных с патологией органов пищеварения. К.: Здоровья, 1989. 208 с.

\section{References}

1. Vyigodner EB. Fizicheskie faktoryi v gastroenterologii. M.: Meditsina, 1987. 304 s. [in Russian].

2. Metodi rannoYi kurortnoYi reabIlItatsIYi hvorih, yakI perenesli holetsistektomIyu, vagotomIyu ta rezektsIyu shlunka: Metod. rekom. / Ukr. NDI MR ta K; Sklad.: Dragomiretska NV, SerebrIna L.O., Bondarchuk G.F. Odesa, 1995. 21s. [in Ukrainian].

3. Parhotik I.I. Fizicheskaya reabilitatsiya pri zabolevaniyah organov bryushnoy polosti. K.: Olimpiyskaya literatura, 2003. 223 s. [in Russian].

4. Samsonov MA, Loranskaya TI, Nesterova AP. Postgastrorezektsionnyie sindromyi (patogenez, klinika, lechenie) /AMN SSSR. M.: Meditsina, 1984. 192 s. [in Russian].

5. Serebrina LA. Reabilitatsiya bolnyih s patologiey organov pischevareniya. K.: Zdorovya, 1989. 208 s. [in Russian].

\section{Цитування на щю статтю:}

Філак ЯФ, Філак ФГ, Цюпак ТЄ. Фізична терапія хворих після хірургічного лікування виразкової хвороби шлунка і дванадцятипалої кишки. Вісник Прикарпатського університету. Серія: Фізична культура. 2019 Берез 26; 33: 102-107

\begin{tabular}{|c|c|}
\hline Відомості про автора: & Information about the author: \\
\hline $\begin{array}{l}\text { Філак Ярослав Феліксович - кандидат наук } 3 \\
\text { фізичного виховання і спорту, доцент, Ужгородсь- } \\
\text { кий національний університет (Ужгород, Україна) }\end{array}$ & $\begin{array}{l}\text { Filak Yaroslav Feliksovych - Candidate of Science } \\
\text { (Physical Education and Sport), Uzhhorod National } \\
\text { University (Uzhhorod, Ukraina) }\end{array}$ \\
\hline \multicolumn{2}{|l|}{$\begin{array}{l}\text { e-mail: yaroslav.filak@uzhnu.edu.ua } \\
\text { https://orcid.org/0000-0002-7510-263X }\end{array}$} \\
\hline $\begin{array}{l}\text { Філак Фелікс Георхійович -кандидат медичних } \\
\text { наук, доцент, Ужгородський національний універ- } \\
\text { ситет (Ужгород, Україна) }\end{array}$ & $\begin{array}{l}\text { Filak Feliks Heorhiiovych - Candidate of Science } \\
\text { (Medicine), Associate Professor (Ph. D.), Uzhhorod } \\
\text { National University (Uzhhorod, Ukraina) }\end{array}$ \\
\hline \multicolumn{2}{|l|}{$\begin{array}{l}\text { e-mail: felix.filak@ uznhu.edu.ua } \\
\text { https://orcid.org/0000-0001-7595-5416 }\end{array}$} \\
\hline $\begin{array}{l}\text { Цюпак Тетьяна Свгенісвна - кандидат педаго- } \\
\text { гічних наук, доцент, Східноєвропейський націо- }\end{array}$ & $\begin{array}{l}\text { Tsiupak Tetiana Yevheniievna-Candidate of Science } \\
\text { (Education), Associate Professor } \quad \text { (Ph. D.), Lesya }\end{array}$ \\
\hline
\end{tabular}




\begin{tabular}{l}
$\begin{array}{l}\text { нальний університет ім. Лесі Українки (Луцьк, } \\
\text { Україна) }\end{array}$ \\
$\begin{array}{l}\text { e-mail: tyatyanacyupak@i.ua } \\
\text { (Lutsk, Ukraina) }\end{array}$ \\
https://orcid.org/0000-0002-7427-8588 \\
\hline
\end{tabular}

УДК 796.89(477)

doi: 10.15330/fcult.33.107-114
Юрій Циба, Ольга Ніколайчук, Антоніна Богданюк

\section{ТЕНДЕНЦІЇ РОЗВИТКУ КЛАСИЧНОГО ПАУЕРЛІФТИНГУ НА СУЧАСНОМУ ЕТАПІ}

3 появою змагань з класичного пауерліфтингу його популярність і масовість постійно

Теоретичний аналіз та узагальнення науково-методичних джерел проводився з метою дослідити тенденції та перспективи розвитку класичного пауерліфтингу в Україні та світі на сучасному етапі.

Документальний метод. В ході дослідження було проаналізовано протоколи змагань чемпіонатів Украӥни та світу з пауерліфтингу та класичного пауерліфтингу за 2008-2017 рр.

Педагогічне спостереження. В прочесі дослідження метод педагогічного спостереження застосовувався з метою визначення кількості учасників на всеукраӥнських та міжнародних змаганнях з пауерліфтингу 2008-2017 років.

Отримані результати та висновки. Пауерліфтинг відносно молодий вид спорту, однак його популярність в усьому світі стрімко зростає. В Україні він належить до пріоритетних неолімпійських видів. Перший чемпіонат з пауерліфтингу в Україні пройшов в 1988 р. у місті Вінниия, 17 березня 1991 р. м. Київ на Установчій конферениї створюється Федерачія пауерліфтингу Украӥни (ФПУ) [1].

У 2013 рочі, IPF приймає рішення про проведення першого чемпіонату світу з класичного пауерліфтингу, який пройшов 11-16 червня 2013 року в місті Суздаль (Росія) [2].

Постійне зростання кількості учасників, рекордів та конкуренції на змагання з класичного пауерліфтингу свідчить про перспективи подальшого розвитку иьього виду змагань.

У 2024 роиі класичний пауерліфтинг буде представлений, як показовий вид на Олімпійський Іграх в Парижі (Франція), щзо в перспективі дає можливість сподіватись на включення класичного пауерліфтингу до програми Олімпійських Ігор.

Ключові слова: пауерліфтинг, змагання, Олімпійські Ігри, чемпіонат.

With the advent of competitions in the classical powerlifting, its popularity and mass are constantly increasing, since it is less costly, comparable to the equipment. In addition, in classical powerlifting, athletes demonstrate their real power capabilities in contrast to the equipping competitions, where the outcome largely depends on the ability of athletes to use special equipment.

Materials and method of research. The following methods were used in the work:

Theoretical analysis and generalization of scientific and methodological sources was conducted with the aim of investigating the trends and perspectives of the development of classical powerlifting in Ukraine and the world at the present stage.

Documentary method. In the course of the research, protocols of competitions of Ukrainian powerlifting and classical powerlifting competitions among boys and girls, juniors and juniors, men and women for 20082017 were analyzed. In addition, the protocols of powerlifting and classical powerlifting championships among all age groups for 2008-2017 years were investigated.

Pedagogical observation. In the process of research, the method of pedagogical observation was used to determine the number of participants in nationwide and international powerlifting competitions 2008-2017. In addition, in the process of pedagogical observation, the number of participants at all-Ukrainian and international competitions in classical powerlifting for 2013-2017 years was analyzed.

About the results and conclusions. Powerlifting is a relatively young sport, but its popularity around the world is growing rapidly. In Ukraine, it belongs to the priority non-Olympic types, since our team, the last four years, is the strongest in the world. Powerlifting as a sport began to develop in the 50-60 years of the last century. In 1964, the exercise bench press was included in the Paralympic Games program (Tokyo, Japan). At first, this type of competition belonged to weightlifting and only since 1989, it is renamed powerlifting.

A comparative analysis of the number of participants in all-Ukrainian and international competitions in powerlifting and classical powerlifting shows a tendency towards a gradual decrease in the mass of powerlifting competitions with a simultaneous increase in its competitions in classical powerlifting. 